\title{
PEER REVIEW IN EFL WRITING CLASSROOMS AT RUSSIAN UNIVERSITIES: CULTURAL FACTORS
}

\author{
(C) Domysheva Svetlana Arkadyevna - Candidate of Philological Sciences, associate professor, Department of \\ Humanities and Foreign Languages, Baikal International Business School, Irkutsk State University, 1, Karl Marx \\ Street, Irkutsk, 664003, Russian Federation. \\ E-mail: katsveta@yandex.ru. ORCID: https://orcid.org/0000-0002-0651-0795 \\ (C) Kopylova Natalia Vladimirovna - Candidate of Philological Sciences, associate professor, Department of \\ Humanities and Foreign Languages, Baikal International Business School, Irkutsk State University, 1, Karl Marx \\ Street, Irkutsk, 664003, Russian Federation. \\ E-mail: n_v_kopylova@mail.ru. ORCID: https://orcid.org/0000-0002-2153-8286
}

\section{ABSTRACT}

The article addresses the issue of using peer review in writing within the field of Teaching English as a Foreign Language (TEFL) at the university level in Russia. Although peer review has been recognized by teachers around the world as an effective technique for improving students' writing skills, there are very few publications on this topic in Russia.

The research aims to determine how often peer review is used in EFL writing classes at Russian universities, what attitudes teachers and students have toward peer review and whether these attitudes are influencedby inherent cultural characteristics. The data for analysis was obtained through online and offline anonymous surveys conducted in a number of Russian universities among random samples of teachers and students.

Based on the findings of these surveys, the authors conclude that peer review is not a very common practice in EFL writing classes in Russia although it is viewed mostly in a positive way by both faculty and students. The study also shows that limitations on using peer review are caused by such inherent cultural characteristics as a high degree of collectivism and high power distance. These cultural values, believed to be typical of Russians, are manifested in educational settings; yet, there is no unanimity among faculty and among students about the extent of this manifestation. Moreover, there is a considerable discrepancy between teachers' and students' views on whether learning should be student- or teacher-centered.

Key words: peer review, TEFL, writing pedagogy, Russian universities, collectivism, power distance, student-centered vs. teacher-centered learning.

Citation. Domysheva S.A., Kopylova N.V. Peer review in EFL writing classrooms at Russian universities: cultural factors. Vestnik Samarskogo universiteta. Istoriia, pedagogika, filologiia [Vestnik of Samara University. History, pedagogics, philology], 2019, Vol. 25, no. 3, pp. 139-147. DOI: http://doi.org/10.18287/25420445-2019-25-2-139-147 [in English]. 


\title{
ВЗАИМНОЕ РЕЦЕНЗИРОВАНИЕ ПИСЬМЕННЫХ ЗАДАНИЙ НА АНГЛИЙСКОМ ЯЗЫКЕ В РОССИЙСКИХ УНИВЕРСИТЕТАХ: КУЛЬТУРНЫЕ ФАКТОРЫ
}

\author{
(C) Домышева Светлана Аркадьевна - кандидат филологических наук, доцент кафедры гуманитарных дисциплин \\ и иностранных языков, Байкальская международная бизнес-школа, Иркутский государственный университет, \\ 664003, г. Иркутск, ул. Карла Маркса, 1. \\ E-mail: katsveta@yandex.ru. ORCID: https://orcid.org/0000-0002-0651-0795 \\ (c) Копылова Наталья Владимировна - кандидат филологических наук, доцент кафедры гуманитарных \\ дисциплин и иностранных языков, Байкальская международная бизнес-школа, Иркутский государственный \\ университет, 664003, г. Иркутск, ул. Карла Маркса, 1. \\ E-mail: n_v_kopylova@mail.ru. ORCID: https://orcid.org/0000-0002-2153-8286
}

\begin{abstract}
АННОТАЦИЯ
В статье рассматривается проблема использования взаимного рецензирования письменных заданий в преподавании английского языка как иностранного в российских университетах. Хотя данный метод был признан эффективным для совершенствования навыков письма, в России этой теме посвящено очень незначительное количество публикаций.

Целью данного исследования стало выявление того, как часто взаимное рецензирование используется на занятиях по обучению письму на английском языке в российских университетах, каково отношение преподавателей и студентов к этому методу, а также определение степени влияния культурных факторов на это отношение. Данные для анализа были получены в результате проведения анонимных онлайн- и офлайн-опросов в ряде российских университетов среди преподавателей и студентов в формате случайной выборки.

На основании опросов авторы делают вывод, что в России взаимное рецензирование не находит широкого применения, хотя этот метод оценивается преимущественно положительно как преподавателями, так и студентами. Проведенное исследование также показывает, что ограниченное использование взаимного рецензирования обусловлено такими культурными особенностями, как высокий уровень коллективизма и высокий индекс дистанции власти. Эти культурные ценности, характеризующие русских как нацию, проявляются в образовательном контексте. Тем не менее среди опрошенных преподавателей и студентов нет единой точки зрения относительно степени их проявления. Кроме того, существуют значительные расхождения между мнениями преподавателей и студентов по поводу того, должно обучение быть центрировано на студентах или на преподавателях.
\end{abstract}

Ключевые слова: взаимное рецензирование, преподавание английского языка как иностранного, обучение письму, российские университеты, коллективизм, дистанция власти, активное обучение vs традиционное обучение.

Цитирование. Domysheva S.A., Kopylova N.V. Peer review in EFL writing classrooms at Russian universities: cultural factors // Вестник Самарского университета. История, педагогика, филология. 2019. T. 25. № 3. C. 139-147. DOI: http://doi.org/10.18287/2542-0445-2019-25-3-139-147.

\section{Introduction}

Russia's integration into global research and educational space is accompanied by adopting teaching strategies, approaches, and methods widely used around the world. One such technique that has proven effective in numerous studies is peer review [Bauler 2013; Bowman \& Robertson 2013; Carson \& Nelson 1996; Connor \&Asenavage 1994; Hyland \& Hyland 2006; Nelson \& Murphy 1993; Ren\& Hu 2011; Tsui\& Ng 2000; Wang 2009], a learning and assessment tool applied in university writing classrooms, including ESL and EFL classrooms, in many countries.

Whereas various aspects of peer review - such as its forms, benefits, best practices, and limitations - have been extensively researched outside of Russia (for example, CompPile, a database of publications in writing studies, lists nearly three thousand items on the subject published in the West), very little research on this topic has been done in Russia [Halmurzaeva\&Masimova 2006; Ostrovskaya\&Vyshegorodtseva 2013; Melyokhina 2014]. The lack of publications on peer review by Russian professionals does not necessarily indicate that this method has not been introduced into the EFL pedagogy in Russia; still, it remains unclear how frequently peer review is used in writing classes at Russian universities and how it is viewed by teachers and students. Furthermore, a number of studies emphasize that in some cultures, mostly in Asia, there may be cultural barriers to effective use of peer review [Carson \& Nelson 1996; Nelson 2000; Ren\& Hu 2011; 
Wang 2009]. Our hypothesis is that cultural issues might have a certain negative impact on using peer review in Russia as well. Therefore, this study aims to discover whether peer review is a common practice, well-integrated into the teaching and learning process in EFL writing classrooms in Russian universities, and whether there is any cultural influence hampering its effective implementation.

\section{Literature review}

As people are both individuals and members of groups, their cultural roots to a large extent determine their perceptions, values, beliefs, and behavioral patterns. One of the best-known theories in cross-cultural studies is GeertHofstede's model of cultural dimensions, which resulted from his extensive research into national values differences [Hofstede 2001]. Nelson [Nelson 2000] claims that two of these cultural dimensions individualism/collectivism and power distance - are especially helpful in understanding ESL and EFL studies. She points out, however, that "cultures vary in their specific manifestations of the dimensions" and "the dimensions may be more applicable to some students than to others due to variations within a culture and the degree to which individual ESL students have adopted target culture norms" [Nelson 2000, p. 76].

The influence of the above-mentioned cultural dimensions on peer review as a pedagogical activity has been thoroughly analyzed in Asian cultures, first of all, in China [Carson 2000; Ren\& Hu 2010; Wang 2009]. According to Hofstede [Hofstede 2001], China is a collectivistic culture, with a high power distance ranking. These values shared by most Chinese are manifested in various contexts, including educational settings. Nelson found that Chinese students, concerned for the feelings of their peers and focused on saving the "face" of every member of the group, were reluctant to do peer review. In their opinion, negative comments, which peer reviews are likely to contain, break harmony and cohesion in the group [Nelson 2000, pp. 78-79]. One more cultural dimension that prevents successful implementation of peer review in China is a big status distance in the classroom, which means preference for teacher-centered pedagogy. As it is the teacher's responsibility to transmit knowledge, Chinese students do not feel that they have any right and competence to be actively involved in the learning process [Nelson 2000, pp. 84-85].

In Hofstede's study Russia also ranks as a collectivistic, high power distance culture. It is more individualistic than China (with the scores 39 and 20 respectively on the 100 scale), but its power distance score is higher than that in China (with the scores 93 and 80 respectively). Both countries are in sharp contrast to the USA, where the score on individualism is 91 and the score on power distance is 40 [Hofstede 2001]. In a number of other studies, Russia is also described as a collectivistic culture, with a significant power distance [Isurin 2011; Kants\&Realo 1999; Realo\&Allik 1999; Tower, Kelly \& Richards 1997; Tu, Ling \&Chang 2011]. As the scores of China and Russia in the two dimensions have a great degree of analogy, it may be assumed that there are similar manifestations of collectivism and high power distance in educational settings in general and in the use of peer review in particular.

This hypothesis is also based on the observations made in several studies into the learning culture of Russian ESL students in the USA [Isurin 2011; Malko 2006; Smith 2000]. According to these studies, Russian students are seen by their American instructors as people who strongly identify themselves with an in-group, who tend to feel morally obliged to help their peers and are unwilling to criticize them, and who are accustomed to teacher-centered instruction. Such descriptions of the Russian learning culture indicate that cultural factors may have a certain impact on effective use of peer review in EFL writing classes in Russia, and the extent of this impact needs to be explored.

\section{Methodology}

In order to obtain data concerning the scope of using peer review in EFL writing classes at Russian universities and concerning attitudes to this activity among teachers and students, two anonymous selfcompletion surveys were conducted in four universities in Irkutsk, Abakan, and St. Petersburg. One of the surveys was held among faculty members who teach writing as part of their EFL courses, and the other survey was carried out among university students learning English at different levels. The survey questionnaires were distributed via face-to-face contacts, e-mail, and Survey Monkey, an online survey tool.

The questionnaire for teachers includes 18 multiple choice questions, most of which require choosing only one option from the list provided. The questionnaire for students is a simplified and shortened version of the teacher questionnaire, and it consists of 14 multiple choice questions. The first four questions in the teacher questionnaire are aimed at obtaining some demographic data about the survey samples - (1) the teacher sample: gender, age, academic degree, work experience, students' level of language proficiency; (2) the student sample: gender, academic year, major. The other questions deal with peer review as such, covering frequency of its use, its effectiveness from the teachers' and students' perspectives, and possible connections between successful implementation of peer review and cultural characteristics of collectivism and high power distance, which are believed to be typical of Russians (these questions will be discussed in the following section).

The teacher sample includes 25 faculty members, among whom are 23 women and 2 men. Most of the teachers are between 30 and 39 years old, have a Candidate of Sciences degree (a Russian academic degree roughly equivalent to $\mathrm{PhD}$ ) and have worked in their professional field for 11-15 years (see Table 1 for more detail).

The participants of the second survey are 119 students, among whom are 92 females and 27 males majoring in humanities, social sciences and applied sciences. Among the respondents there are 30 first-year students, 26 second-year students, 24 third-year students, 23 fourth-year students, 8 graduate students studying 
Age, Academic Degree and Work Experience of the Faculty Sample

\begin{tabular}{|c|c|c|c|c|c|c|}
\hline & \multicolumn{6}{|c|}{ Age } \\
\hline & Under 25 & $25-29$ & $30-39$ & $40-49$ & $50-59$ & $60+$ \\
\hline \multirow{3}{*}{$\begin{array}{l}\text { Number } \\
\text { of people }\end{array}$} & - & 1 & 18 & 5 & - & 1 \\
\hline & \multicolumn{6}{|c|}{ Academic degree } \\
\hline & $\begin{array}{c}\text { Master's } \\
\text { degree }\end{array}$ & $\begin{array}{c}\text { Specialist } \\
\text { degree }\end{array}$ & $\begin{array}{l}\text { Candidate } \\
\text { of Sciences }\end{array}$ & $\mathrm{PhD}$ & $\begin{array}{l}\text { Doctor of } \\
\text { Sciences }\end{array}$ & \\
\hline \multirow{4}{*}{$\begin{array}{l}\text { Number } \\
\text { of people }\end{array}$} & - & 6 & 19 & - & - & \\
\hline & \multicolumn{6}{|c|}{ Work experience } \\
\hline & $1-2$ years & $3-5$ years & $6-10$ years & $11-15$ & $16-20$ & More than \\
\hline & & & & years & years & 20 years \\
\hline $\begin{array}{l}\text { Number } \\
\text { of people }\end{array}$ & - & - & 6 & 14 & 2 & 3 \\
\hline
\end{tabular}

for their Master's degree and 8 students studying for their Candidate of Sciences degree. The survey used stratified random sampling aimed at gathering information about students at various academic levels.

\section{Data analysis and discussion}

The scope of peer review use in EFL writing classes at Russian universities

According to the survey among the faculty, 60 percent of the respondents (15 out of 25 people) have used peer review in their writing classrooms. 8 teachers say that they use peer review approximately once per semester; 6 teachers use it on a more regular basis, several times per semester, and one teacher used to do it in the past but does not practice it any longer.

The survey conducted among the students shows that approximately 56 percent of the sample (67 out of 119 people) have tried peer review in their writing assignments. Among the 52 students who have never done peer review, 37 students say that they would like to try it, while 15 students do not think it is worth trying.

In order to understand how extensive the scope of using peer review in EFL writing classes in Russia is, we compared our findings with the results of a similar survey at a private master's-level comprehensive university in the southeastern United States [Brammer\& Rees 2007]. All of the 22 faculty members who completed the survey regularly practiced peer review in their writing courses. 16 teachers (approximately 73 percent) said that they always or usually did it, and 6 teachers (approximately 27 percent) said that they seldom or occasionally did it. The survey among 328 students also showed that all the students were required to do peer review, more or less frequently. About twothirds of the student respondents used peer review for more than half of their major writing assignments, and 20.4 percent said that they asked their classmates to peer review even when it was not required by the instructor [Brammer\& Rees 2007, pp. 74-77].

The results of the U.S. survey indicate that peer review is an inseparable part of writing courses at American universities as 100 percent of the teaching staff practice it in their writing classrooms and 100 percent of the students have to do it. In Russia, however, as our survey shows, peer review used by approximately 60 percent of the teachers is not a very common learning tool. At the same time, the findings of the two surveys cannot be compared in a simplistic way as there are a number of complicating factors to be further considered. First, the American writing courses mentioned above teach students how to write in their native language, not in a foreign language. Our survey, however, analyzes the use of peer review in EFL writing classes, while it remains unknown whether this technique finds any application when students write in Russian. Second, whereas at American universities a writing course is a separate entity, at Russian universities writing in English is an integrated part of the English language course, together with other aspects such as reading, listening and speaking.

Attitudes to peer review in EFL writing classes at Russian universities

As the survey shows, faculty members have mixed feelings about peer review. Among the 25 surveyed, 14 teachers find peer review effective ( 3 of them have never tried it); 10 teachers cannot make evaluative judgments about this method (6 of them have never used peer review), and one teacher considers peer review ineffective. Among the 10 teachers who have never used peer review, 7 teachers say that they would like to try it.

Generally, most of the students demonstrate quite a positive attitude to peer review: 77 students (64.7 percent), including 42 students who have tried it, think peer review is an effective technique; 23 students (19.3 percent), including 9 students who have tried it, cannot say whether or not peer review is effective; 19 students (16 percent), including 16 students who have tried it, do not think peer review is effective. Among the students who have tried peer reviewing 62.7 percent evaluate peer review as a helpful method whereas 23.8 percent do not see much value in this activity.

Brammer and Rees study [Brammer\&Rees 2007] revealed more positive attitudes to peer review. Most of the faculty respondents share the view that peer review is a valuable part of the writing process (mean $=3.77$ on a 5-point scale). Among the students surveyed, approximately 43.3 percent think that peer review is usually or always helpful; 31.1 percent consider it 
occasionally helpful; 18 percent seldom find it helpful, and 4.6 percent say it is not helpful at all.

Quite limited use of peer review in EFL writing classes at Russian universities may be caused by several reasons, for example, by poor teacher awareness of this method. Likewise, mixed feelings about peer review among students may be related to the fact that EFL learners may distrust their peers' responses as they all are developing their language proficiency. Still, there is a great probability that there are certain underlying cultural factors behind the current situation. Therefore, the questionnaire includes eight questions designed to determine the presence of such cultural characteristics as a high degree of collectivism and a high degree of power distance in educational settings.

Collectivism

The key features of collectivism are a strong sense of belonging to a certain group and maintaining harmony and good relations within this group. It is important to save the "face" of every member of the group, and disagreeing or criticizing is to be avoided. Such attitudes, however, apply only to the members of the group, not to people outside the group. The questionnaires for teachers and students contained four statements describing possible manifestations of collectivistic patterns of behavior in doing peer reviews. The respondents needed to express their agreement or disagreement with these statements.

The results of the survey among the faculty show that most teachers strongly believe that being on the collectivistic end of the scale causes considerable psychological discomfort among Russian students when they have to do peer reviews. It makes them reluctant to come up with critical comments and to be objective when assessing their group members. This viewpoint is shared by both the teachers who use peer review in their writing activities (Group 1 in the chart below, consisting of 15 teachers) and the teachers who have never tried peer review and consider this issue hypothetically, relying on their general teaching experience (Group 2 in the chart below, consisting of 10 teachers), Table 2.

The results of the student survey differ considerably from the results of the faculty survey. Whereas the overwhelming majority of the students agree with the first two statements regarding the preferred conditions of doing peer reviews (statement 1: 91 students agree, 28 disagree; statement 2: 87 agree, 32 disagree), there are more respondents who disagree that maintaining harmony in the group and avoiding criticism of group members' writing in order to save their "face" are of great importance (statement 3: 69 disagree, 50 agree; statement 4: 73 disagree, 46 agree). This viewpoint is shared by both the students who have tried doing peer reviews in their writing activities (Group 1 in the chart below) and the students who have never tried peer reviews and consider this issue hypothetically, relying on their experience in other learning activities (Group 2 in the chart below), Table 3.

There is a clear discrepancy between the faculty's and the students' views of collectivism and its impact on peer review. From the teachers' perspective, students value cohesion and good relations within their group and they place a high importance on keeping a friendly atmosphere devoid of any criticism. The students surveyed do not share these opinions so unanimously; in fact, most students display individualistic attitudes.

\section{Power distance}

In educational settings power distance refers to the distance between a teacher and a student. High power distance means preference for teacher-centered pedagogy, where the teacher is the sole authority, responsible for transmitting knowledge to the students whose role is to passively receive this knowledge. The teacher functions as "the sage on the stage" and does not expect students to actively participate in their own learning.

Peer Review and Collectivism (Faculty's Perspective)

\begin{tabular}{|c|c|c|c|c|c|}
\hline Name & Gr. & $\begin{array}{l}\text { Strongly } \\
\text { disagree }\end{array}$ & Disagree & Agree & $\begin{array}{c}\text { Strongly } \\
\text { agree }\end{array}$ \\
\hline \multirow{3}{*}{$\begin{array}{l}\text { 1. My students would feel more comfortable } \\
\text { and would provide more critical comments if } \\
\text { they did peer reviews anonymously, without } \\
\text { knowing whose work it is }\end{array}$} & Gr. 1 & - & 1 & 8 & 6 \\
\hline & Gr. 2 & - & 1 & 9 & - \\
\hline & Total & - & 2 & 17 & 6 \\
\hline \multirow{4}{*}{$\begin{array}{l}\text { 2. My students would feel more comfortable } \\
\text { and would provide more critical comments if } \\
\text { they reviewed work of somebody from } \\
\text { another group whom they do not know } \\
\text { personally }\end{array}$} & Gr. 1 & - & 1 & 8 & 6 \\
\hline & & & & & \\
\hline & Gr. 2 & - & 3 & 6 & 1 \\
\hline & Total & - & 4 & 14 & 7 \\
\hline \multirow{3}{*}{$\begin{array}{l}\text { 3. When students do peer reviews, they tend } \\
\text { to apply elevated grades or to award the same } \\
\text { grade to everyone because it is very important } \\
\text { for them to keep harmony in the group }\end{array}$} & Gr. 1 & - & 3 & 9 & 3 \\
\hline & Gr. 2 & - & 3 & 6 & 1 \\
\hline & Total & - & 6 & 15 & 4 \\
\hline \multirow{3}{*}{$\begin{array}{l}\text { 4. Students are unwilling to point out errors } \\
\text { and shortcomings of their classmates' writing } \\
\text { because there is a "face" problem }\end{array}$} & Gr. 1 & - & 7 & 7 & 1 \\
\hline & Gr. 2 & - & 2 & 7 & 1 \\
\hline & Total & - & 9 & 14 & 2 \\
\hline
\end{tabular}


The questionnaires for teachers and students contained four statements describing possible manifestations of high power distance in doing peer reviews. The respondents needed to express their agreement or disagreement with these statements.

According to the survey, teachers show a certain extent of disagreement concerning high power distance. The faculty surveyed form two more or less equal groups which have the opposite views of students' ability to do peer reviews (statement 1 in Fig. 4 below). 12 teachers believe that their students are not able to do peer reviews well, whereas 13 teachers disagree. Although it is reasonable to assume that the ability of students to do peer reviews effectively depends on their level of language proficiency, the survey does not confirm this assumption. Teachers whose students' level of language proficiency is high (assessed as $\mathrm{C} 1$ or $\mathrm{C} 2$ ) are found in both of the above-mentioned groups.

Similarly, there is no agreement among faculty concerning the authority and the role of the teacher in the classroom. Responses to statements 2, 3 and 4 in Table 4 below highlight the presence of two opposite teaching paradigms in Russian universities - teachercentered (statements 2 and 3) and learner-centered (statement 4). The survey shows that there is no unanimous understanding of relationships between faculty and students and of distributing responsibility in the classroom.

The student survey indicates that among students, unlike teachers, the viewpoint that students are competent enough to do peer reviews dominates (83 out of

Peer Review and Collectivism (Students' Perspective)

Table 3

\begin{tabular}{|c|c|c|c|c|c|}
\hline Name & Gr. & $\begin{array}{l}\text { Strongly } \\
\text { disagree }\end{array}$ & Disagree & Agree & $\begin{array}{c}\text { Strongly } \\
\text { agree }\end{array}$ \\
\hline \multirow{3}{*}{$\begin{array}{l}\text { 1. I would feel more comfortable and would } \\
\text { provide more critical comments if I did peer } \\
\text { reviews anonymously, without knowing whose } \\
\text { work it is }\end{array}$} & Gr. 1 & 3 & 12 & 35 & 17 \\
\hline & Gr. 2 & 2 & 11 & 31 & 8 \\
\hline & Total & 5 & 23 & 66 & 25 \\
\hline \multirow{3}{*}{$\begin{array}{l}\text { 2. I would feel more comfortable and would } \\
\text { provide more critical comments if I reviewed } \\
\text { work of somebody from another group whom I } \\
\text { do not know personally }\end{array}$} & Gr. 1 & 5 & 11 & 43 & 8 \\
\hline & Gr.2 & - & 16 & 31 & 5 \\
\hline & Total & 5 & 27 & 74 & 13 \\
\hline \multirow{3}{*}{$\begin{array}{l}\text { 3. Keeping harmony in my group is more } \\
\text { important than expressing critical opinions }\end{array}$} & Gr. 1 & 5 & 36 & 21 & 5 \\
\hline & Gr. 2 & 2 & 26 & 17 & 7 \\
\hline & Total & 7 & 62 & 38 & 12 \\
\hline \multirow{3}{*}{$\begin{array}{l}\text { 4. It is difficult for me to point out errors and } \\
\text { shortcomings of my classmates' writing } \\
\text { because I do not want to offend them with my } \\
\text { criticism }\end{array}$} & Gr. 1 & 8 & 34 & 24 & 1 \\
\hline & Gr. 2 & 5 & 26 & 16 & 5 \\
\hline & Total & 13 & 60 & 40 & 6 \\
\hline
\end{tabular}

Peer Review and High Power Distance (Faculty's Perspective)

\begin{tabular}{|c|c|c|c|c|c|}
\hline Name & Gr. & $\begin{array}{l}\text { Strongly } \\
\text { disagree }\end{array}$ & Disagree & Agree & $\begin{array}{c}\text { Strongly } \\
\text { agree }\end{array}$ \\
\hline \multirow{3}{*}{$\begin{array}{l}\text { 1. Peer review is too challenging for students, } \\
\text { and they are not able to recognize errors and } \\
\text { give good comments }\end{array}$} & Gr. 1 & 3 & 6 & 5 & 1 \\
\hline & Gr. 2 & - & 4 & 6 & - \\
\hline & Total & 3 & 10 & 11 & 1 \\
\hline \multirow{3}{*}{$\begin{array}{l}\text { 2. Teachers are solely responsible for making } \\
\text { corrections and for explaining how to write. } \\
\text { Students' responsibility is just to follow the } \\
\text { teacher's guidelines }\end{array}$} & Gr. 1 & 2 & 6 & 6 & 1 \\
\hline & Gr. 2 & - & 4 & 5 & 1 \\
\hline & Total & 2 & 10 & 11 & 2 \\
\hline \multirow{3}{*}{$\begin{array}{l}\text { 3. In Russia, teacher-centered approaches } \\
\text { produce better results as students are not } \\
\text { ready to be active learners }\end{array}$} & Gr. 1 & 1 & 6 & 8 & - \\
\hline & Gr. 2 & - & 3 & 7 & - \\
\hline & Total & 1 & 9 & 15 & - \\
\hline \multirow{3}{*}{$\begin{array}{l}\text { 4. Students now have more autonomy in } \\
\text { learning, and the teacher's role is to help them } \\
\text { learn }\end{array}$} & Gr. 1 & - & 7 & 8 & - \\
\hline & Gr. 2 & - & 2 & 7 & 1 \\
\hline & Total & - & 9 & 15 & 1 \\
\hline
\end{tabular}


Peer Review and High Power Distance (Students' Perspective)

\begin{tabular}{|c|c|c|c|c|c|}
\hline Name & Gr. & $\begin{array}{l}\text { Strongly } \\
\text { disagree }\end{array}$ & Disagree & Agree & $\begin{array}{c}\text { Strongly } \\
\text { agree }\end{array}$ \\
\hline \multirow{3}{*}{$\begin{array}{l}\text { 1. Peer review is too challenging for me. I do } \\
\text { not think I am able to recognize errors and } \\
\text { give good comments on my peers' writing }\end{array}$} & Gr. 1 & 12 & 38 & 15 & 2 \\
\hline & Gr. 2 & 5 & 28 & 16 & 3 \\
\hline & Total & 17 & 66 & 31 & 5 \\
\hline \multirow{3}{*}{$\begin{array}{l}\text { 2. Teachers are solely responsible for making } \\
\text { corrections and for explaining how to write. } \\
\text { Students' responsibility is just to follow the } \\
\text { teacher's guidelines }\end{array}$} & Gr. 1 & 5 & 28 & 28 & 6 \\
\hline & Gr. 2 & 3 & 14 & 31 & 4 \\
\hline & Total & 8 & 42 & 59 & 10 \\
\hline \multirow{3}{*}{$\begin{array}{l}\text { 3. In Russia, teacher-centered approaches } \\
\text { produce better results as students are not } \\
\text { ready to be active learners }\end{array}$} & Gr. 1 & 7 & 34 & 21 & 5 \\
\hline & Gr. 2 & 7 & 29 & 15 & 1 \\
\hline & Total & 14 & 63 & 36 & 6 \\
\hline \multirow{3}{*}{$\begin{array}{l}\text { 4. Students now have more autonomy in } \\
\text { learning, and the teacher's role is to help them }\end{array}$} & Gr. 1 & 2 & 19 & 35 & 11 \\
\hline & Gr. 2 & 1 & 7 & 38 & 6 \\
\hline & Total & 3 & 26 & 73 & 17 \\
\hline
\end{tabular}

119 students believe so). According to the survey, the majority of the students agree that teachers are more responsible for the educational process than learners themselves; however, the numerical difference between the two groups is not very big (69 students versus 50 students). At the same time, most of the respondents support the idea that students are active and autonomous participants of the learning process, not passive recipients of information (statement 3: 77 students versus 42 students; statement 4: 90 students versus 29 students), Table 5.

\section{Conclusions}

The first part of the study aimed at discovering how extensively peer review is used in EFL writing classes at Russian universities and how it is viewed by both faculty and students has produced the following results. Unlike American universities, where peer review has become a standard routine in writing courses [Brammer\& Rees 2007], in Russia it is not a wellestablished component of the writing process yet. Nowadays, slightly more than half of the faculty (60 percent) use peer review in their writing classes. Since there is no data on this issue prior to the current study, it is impossible to observe the dynamics of peer review usage in EFL writing pedagogy in Russia. Yet, further research could show whether or not peer review is becoming more popular.

The survey shows that attitudes to peer review are generally positive. The majority of the faculty and the students believe that peer review improves students' writing skills. It means that although there are teachers and students who are opposed to this technique and who do not find it effective, peer review is quite favorably accepted in the EFL community at Russian universities.

The purpose of the second part of the study was to determine whether cultural norms traditionally ascribed to Russia, such as collectivistic values and high power distance, have any impact on implementing peer review in writing classes. The survey has revealed a certain discrepancy in opinions expressed by the faculty and by the students. Whereas both of these groups believe that it is more comfortable to do peer review anonymously or not knowing whose work is being reviewed, they have different views concerning keeping harmony in the group and saving the group mates' "face". Unlike faculty, the majority of whom believe that these collectivistic patterns of behavior are typical of their students, students themselves mostly do not attach so much importance to these values, thus, displaying a considerable degree of individualism.

Whereas teachers are more cautious in assessing their students' ability to do good peer reviews (only 52 percent believe that peer review is a task with which students can cope successfully), students themselves are more confident of their skills $(69.7$ percent do not think that peer review is too challenging). In other words, students want to more actively participate in the educational process.

The survey questions about power distance reveal that facultyare more or less equally divided into two groups. One of the groups believes in the principles of teacher-centered pedagogy, and the other one supports the ideas of learner-centered pedagogy. Similar results can be observed in the student sample, where many students tend to show willingness to be more actively involved in the learning process. These findings may indicate that the Russian higher education system is shifting from the older teacher-centered paradigm (characterized by high power distance) to the new learnercentered paradigm (characterized by low power distance).

Based on these findings, we can draw a conclusion that cultural background has a certain impact on the effective use of peer review in EFL writing pedagogy. Still, as the values of collectivism and high power distance considered typical of Russians seem to be undergoing changes, this impact should not be overestimated. 


\section{References}

Bowman, Robertson 2013 - Bowman I.K., Robertson J. Sequenced Peer Revision: Creating Competence and Community. The CATESOL Journal, 2012/2013, no. 24.1, pp. 98-111. Available at: https://files.eric.ed.gov/fulltext/ EJ1111900.pdf [in English].

Brammer, Rees 2007 - Brammer C., Rees M. Peer Review From the Students' Perspective: Invaluable or Invalid? Composition Studies, 2007, Vol. 35 (2), pp. 71-85. Available at: https://www.uc.edu/content/dam/uc/journals/ composition-studies/docs/backissues/3 5-2/ Brammer\%20and\%20Rees\%2035.2.pdf [in English].

Carson, Nelson 1996 - Carson J., Nelson G. Chinese Students' perception of ESL Peer Response Group Interaction. Journal of Second Language Writing, Vol. 5, Issue 1, January 1996, pp. 1-19. DOI: https://doi.org/ 10.1016/S1060-3743(96)90012-0 [in English].

Connor, Asenavage 1994 - Connor U., Asenavage K. Peer Response Groups in ESL Writing Classes: How Much Impact on Revision? Journal of Second Language Writing, 1994, no. 3, pp. 257-276 [in English].

Hofstede 2001 - Hofstede G. (2001) Culture's Consequences. Comparing Values, Behaviors, Institutions, and Organizations Across Nations, $2^{\text {nd }}$ ed. Sage, Thousand Oaks, CA. Available at: https://digitalcommons.usu.edu/ unf_research/53/. [in English].

Hyland 2006 - Hyland K., Hyland F. Feedback on Second Language Students' Writing.Language Teaching. Cambridge: Cambridge University Press, 2006, Vol. 39 (2), pp. 83-101. DOI: http://dx.doi.org/10.1017/S0261444806003399 [in English].

Isurin 2011 - Isurin L. Russian Diaspora: Culture, Identity, and Language Change. NY: Walter de Gruyter, 2011, 234 p. [in English].

Kants, Realo 1999 - Kants L., Realo A. Meta-Level Collectivism in Estonia and Finland. A Journal of the Humanities and Social Sciences, 1999, no. 1/2, Vol. 3 (53/ 48), pp. 3-18 [in English].

Malko 2006 - Malko V.A. A Comparative Analysis of American and Russian ESL/EFL Classroom Cultures. The CATESOL Journal, 2006, no. 18.1, pp. 122-137. Available at: http://www.catesoljournal.org/wp-content/ uploads/2014/07/CJ18_malko.pdf [in English].

Nelson, Murphy 1993 - Nelson G., Murphy J. Peer Response Groups: Do L2 Writers Use Peer Comments in Revising Their Drafts?. TESOL Quarterly, 1993, no. 27, pp. 135-142. DOI: 10.2307/3586965 [in English].

Nelson 2000 - Nelson G. Individualism-Collectivism and Power Distance: Applications for the English as a Second Language Classroom. The CATESOL Journal, 2000, no. 12.1, pp. 73-91. Available at: http://www.catesoljournal.org/ wp-content/uploads/2014/07/CJ12_nelson.pdf [in English].

Realo, Allik 1999 - Realo A., Allik J. Across-Cultural Study of Collectivism: A Comparison of American, Estonian and Russian Students. Journal of Social Psychology, 1999 , no. 139, pp. 133-142. DOI: $10.1080 / 00224549909598367$ [in English].

Ren, Hu 2012 - Ren H., Hu G. Peer Review and Chinese EFL/ESL Student Writers. English Australia Journal, 2012, Vol. 27(2), pp. 3-16. Available at: https:// eajournal.partica.online/digital/english-australia-journal272/flipbook/1 [in English].
Smith 2000 - Smith I. Culture Clash in the English as a Second Language Classroom: Russian Students in America. The CATESOL Journal, 2000, no. 12.1, pp. 93-116. Available at: http://www.catesoljournal.org/wp-content/uploads/2014/ 07/CJ12_smith.pdf [in English].

Tower, Kelly, Richards 1997 - Tower R.K., Kelly C., Richards $A$. Individualism, collectivism and Reward Allocation: A Cross-Cultural Study in Russia and Britain. Journal of Social Psychology, 1997, no. 36, pp. 331-345. DOI: 10.1111/j.2044-8309.1997.tb01135.x [in English].

Tsui, Ng 2000 - Tsui A.B.M., Ng M. Do Secondary L2 Writers Benefit From Peer Comments?. Journal of Second Language Writing, 2000, no. 9, pp. 147-170. DOI: https:// doi.org/10.1016/S1060-3743(00)00022-9 [in English].

Tu, Lin, Chang $2011-T u$ Y.T., Lin S.Y., Chang Y.Y. A Cross-Cultural Comparison by Individualism/ Collectivism among Brazil, Russia, India and China. International Business Research, 2011, no. 4 (2), pp. 175182. DOI: $10.5539 /$ ibr.v4n2p175 [in English].

Wang 2009 - Wang H.C. Taiwanese Students' Perceptions of Writing Commentaries: Revisiting Culture. The International Journal of Language, Society, and Culture, 2009, no. 28, pp. 82-91 [in English].

Melekhina 2014 - Melekhina E.A. Tekhnologii otsenivaniya esse pri obuchenii aspirantov i magistrantov pis'mu dlya akademicheskikh tselei [Essay Assessment Technology in Teaching Writing for Academic Purposes to Master and Graduate Students]. Vestnik TGPU [Tomsk State Pedagagocial University Bulletin], 2014, no. 10 (151), pp. 202-206. Available at: https://vestnik.tspu.edu.ru/en/ archive html ? year $=2014 \&$ issue $=10 \&$ article_id $=4881$ [in Russian].

Ostrovskaya, Vyshegorodtseva 2013 - Ostrovskaya E.S., Vyshegorodtseva O.V. Academic Writing: kontseptsiya i praktika akademicheskogo pis'ma na angliiskom yazyke [Academic Writing: Concept and Practice of Academic Writing in English]. Vysshee obrazovanie $v$ Rossii [Higher Education in Russia], 2013, no. 7, pp. 104-113. Available at: https://publications.hse.ru/mirror/pubs/share/folder/ 34sg6c13sx/direct/111589237 [in Russian].

Halmurzaeva, Masimova 2006 - Halmurzaeva A.F., Masimova A.D. Preimushchestva vzaimoproverki kak osnovnogo zvena protsessa napisaniya esse [Benefits of Peer Review as the Main Element of Essay Writing]. AUCA Academic Review, 2006, pp. 183-188. Available at http:// elibrary.auca.kg/bitstream/123456789/308/1/ Halmurzaeva_Masimova_2006_4.pdf. [in Russian].

Bauler 2012/2013 - Bauler C.V. Online Forum Discussions and the Development of Opinions in College-Level ESL Writing. The CATESOL Journal, 2012/2013, no. 24.1, pp. 112-121. Available at https://files.eric.ed.gov/fulltext/ EJ1111889.pdf [in English].

\section{Библиографический список}

Bauler 2013 - Bauler C.V. Online Forum Discussions and the Development of Opinions in College-Level ESL Writing // The CATESOL Journal. 2013. № 24.1. P. 112-121. URL: https://files.eric.ed.gov/fulltext/EJ1111889.pdf.

Bowman, Robertson 2013 - Bowman I. K., Robertson J. Sequenced Peer Revision: Creating Competence and Community // The CATESOL Journal. 2013. № 24.1. P. 98-111. URL: https://files.eric.ed.gov/fulltext/EJ1111900.pdf.

Brammer, Rees 2007 - Brammer C., Rees M. Peer Review From the Students' Perspective: Invaluable or Invalid? // Composition Studies. 2007. Vol. 35 (2). P. 71-85. URL: 
Domysheva S.A., Kopylova N.V.

https://www.uc.edu/content/dam/uc/journals/compositionstudies/docs/backissues/35-2/Brammer\%20and $\% 20$ Rees\%2035.2.pdf.

Carson, Nelson 1996 - Carson J., Nelson G. Chinese Students' perception of ESL Peer Response Group Interaction // Journal of Second Language Writing. 1996. № 5. P. 1-19. DOI: https://doi.org/10.1016/S10603743(96) $90012-0$.

Connor, Asenavage 1994 - Connor U., Asenavage K. Peer Response Groups in ESL Writing Classes: How Much Impact on Revision? // Journal of Second Language Writing. 1994. № 3. P. 257-276.

Hofstede 2001 - Hofstede G. Culture's Consequences. Comparing Values, Behaviors, Institutions, and Organizations Across Nations. Thousand Oaks, CA: Sage, 2001. URL: https://digitalcommons.usu.edu/unf_research/53.

Hyland 2006 - Hyland K., Hyland F. Feedback on Second Language Students' Writing.Language Teaching. Cambridge: Cambridge University Press, 2006. Vol. 39 (2). P. 83-101. DOI: http://dx.doi.org/10.1017/S0261444806003399.

Isurin 2011 - Isurin L. Russian Diaspora: Culture, Identity, and Language Change. NY: Walter de Gruyter, 2011. 234 p.

Kants, Realo 1999 - Kants L., Realo A. Meta-Level Collectivism in Estonia and Finland // A Journal of the Humanities and Social Sciences. 1999. No. 1/2. Vol. 3 (53/48). P. 3-18.

Malko 2006 - Malko V.A. A Comparative Analysis of American and Russian ESL/EFL Classroom Cultures // The CATESOL Journal. 2006. № 18.1. P. 122-137. URL: http://www.catesoljournal.org/wp-content/uploads/2014/07/ CJ18_malko.pdf.

Nelson, Murphy 1993 - Nelson G., Murphy J. Peer Response Groups: Do L2 Writers Use Peer Comments in Revising Their Drafts? // TESOL Quarterly. 1993. № 27. P. 135-142. DOI: $10.2307 / 3586965$.

Nelson 2000 - Nelson G. Individualism-Collectivism and Power Distance: Applications for the English as a Second Language Classroom // The CATESOL Journal. 2000. № 12.1. P. 73-91. URL: http://www.catesoljournal.org/wpcontent/uploads/2014/07/CJ12_nelson.pdf.

Realo, Allik 1999 - Realo A., Allik J. Across-Cultural Study of Collectivism: A Comparison of American, Estonian and Russian Students // Journal of Social Psychology. 1999. № 139. P. 133-142. DOI: 10.1080/00224549909598367.
Ren, Hu 2012 - Ren H., Hu G. Peer Review and Chinese EFL/ESL Student Writers // English Australia Journal. 2012. Vol. 27 (2). P. 3-16. URL: https://eajournal.partica.online/ digital/english-australia-journal-272/flipbook/1/

Smith 2000 - Smith I. Culture Clash in the English as a Second Language Classroom: Russian Students in America // The CATESOL Journal. 2000. № 12.1. P. 93-116. URL: http://www.catesoljournal.org/wp-content/uploads/2014/07/ CJ12_smith.pdf.

Tower, Kelly, Richards 1997 - Tower R.K., Kelly C., Richards A. Individualism, collectivism and Reward Allocation: A Cross-Cultural Study in Russia and Britain // Journal of Social Psychology. 1997. № 36. P. 331-345. DOI: 10.1111/j.2044-8309.1997.tb01135.x.

Tsui, Ng 2000 - Tsui A.B.M., Ng M. Do Secondary L2 Writers Benefit From Peer Comments? // Journal of Second Language Writing. 2000. № 9. P. 147-170. DOI: https://doi.org/10.1016/S1060-3743(00)00022-9.

Tu, Lin, Chang $2011-T u$ Y.T., Lin S.Y., Chang Y.Y. A Cross-Cultural Comparison by Individualism/ Collectivism among Brazil, Russia, India and China // International Business Research. 2011. № 4 (2). P. 175182. DOI: 10.5539/ibr.v4n2p175.

Wang 2009 - Wang H.C. Taiwanese Students' Perceptions of Writing Commentaries: Revisiting Culture // The International Journal of Language, Society, and Culture. 2009. № 28. P. 82-91.

Мелехина 2014 - Мелехина E.A. Технологии оценивания эссе при обучении аспирантов и магистрантов письму для академических целей // Вестник ТГПУ. 2014. № 10 (151). С. 202-206. URL: https://vestnik.tspu.edu.ru/en/archive.html? year= $2014 \&$ issue $=10 \&$ article_id $=4881$

Островская, Вышегородцева 2013 - Островская Е.С., Вышегородцева O.B. Academic Writing: концепция и практика академического письма на английском языке // Высшее образование в России. 2013. № 7. C. 104-113. URL: https://publications.hse.ru/mirror/pubs/ share/folder/34sg6c13sx/direct/111589237.

Халмурзаева, Масимова 2006 - Халмурзаева А.Ф., Масимова А.Д. Преимущества взаимопроверки как основного звена процесса написания эссе // AUCA Academic Review. 2006. C. 183-188. URL: http:// elibrary.auca.kg/bitstream/ 123456789/308/1/Halmurzaeva_ Masimova_2006_4.pdf. 